\title{
Screening and characterisation of virus causing yellow leaf disease of Tephrosia in Ethiopia
}

\author{
Alok Kumar $^{1,2}$ (D) $\cdot$ Jean Hanson ${ }^{1} \cdot$ Chris S. Jones $^{1} \cdot$ Yilikal Assefa $^{1} \cdot$ Fikerte Mulatu $^{1}$ \\ Received: 2 January 2020 /Revised: 4 May 2020 / Accepted: 14 May 2020/Published online: 28 May 2020 \\ (C) The Author(s) 2020
}

\begin{abstract}
Tephrosia, an important medicinal plant, and a potential livestock feed, was found to be affected by a leaf yellowing disease at the Ziway field site of the International Livestock Research Institute. A total of fifty samples from 300 plants were collected from twenty Tephrosia species in three consecutive planting seasons; 2015, 2016 and 2017. The samples were screened for viral infection by dot-blot assay with antiserum targetting eight viruses. RT-PCR of dot-blot positive samples using virus specific primers gave an amplification product of the expected size ( $867 \mathrm{bp}$ ) only for cucumber mosaic virus (CMV) in Tephrosia senna. The amplified products were sequenced; coat protein sequence (657 bp) extracted, and submitted to NCBI database (Tep-Et; KY041651). Sequence alignment and phylogenetic analyses indicated that the isolate, Tep-Et, shared maximum identity [88.897.5\% nucleotide (nt) and 89.4-96.3\% amino acid (aa)] with CMV belonging to members of subgroup-I. To our knowledge, this is the first report of molecular characterisation of a CMV isolate infecting a new host, T. senna in Ethiopia.
\end{abstract}

Keywords Tephrosia $\cdot$ Cucumber mosaic virus $\cdot$ Dot-blot $\cdot$ Forage $\cdot$ Phylogenetic analysis $\cdot$ RT-PCR

The genus Tephrosia, from the family Leguminosae, includes approximately 400 plant species, which are well known for their medicinal values (Qureshi et al. 2010; Dzenda et al. 2007). Many species of Tephrosia have been found to be nutritionally rich and considered to be economically viable with potential to use as animal feed (Babayemi and Bamikole 2006; Akande et al. 2008; Mbomi et al. 2011). The International Livestock Research Institute (ILRI) conserves 345 genotypes of Tephrosia germplasm representing 40 species collected from 45 countries, held in its genebank and available under the International Treaty on Plant Genetic Resources for Food and Agriculture.

Electronic supplementary material The online version of this article (https://doi.org/10.1007/s13313-020-00717-5) contains supplementary material, which is available to authorized users.

Alok Kumar alok.igib@gmail.com

1 Feed and Forage Development, International Livestock Research Institute, Box 5689, Addis Ababa, Ethiopia

2 Present address: School of Plant Sciences, College of Agriculture and Environmental Sciences, Haramaya University, Box-138, Dire Dawa, Ethiopia
During the routine seed multiplication process of ILRI's genebank accessions, seeds of 46 germplasm accessions from 20 Tephrosia species (Suppl. Table 1) were germinated in the glasshouse during the planting season 2015, 2016 and 2017 at ILRI Ethiopia in Addis Ababa, and were observed for the development of any disease symptoms. All of the germinated plants were transferred to small pots and checked for virus infection by dot-blot assay using the standard protocol (Wang et al. 2012), and antisera to alfalfa mosaic virus (AMV), bean common mosaic virus (BCMV), bean yellow mosaic virus (BYMV), cowpea mottle virus (CPMoV), $\mathrm{cu}$ cumber mosaic virus (CMV), peanut mottle virus (PeMoV), pea seed borne mosaic virus (PsbMV) and soybean mosaic virus (SMV) to ensure the maintenance of disease free plants for seed multiplication. All healthy plants were transferred to the ILRI field sites located in Ziway (7.9000, 38.7348), Bishoftu $(8.7895,38.9863)$, Soddo $(6.8346,37.7490)$, and Shola $(9.0156,38.8147)$, Ethiopia. While monitoring the plants at the field sites, a yellowing symptom was observed in some of the Tephrosia accessions, indicating the existence of disease in the plants. Consequently, a total of 50 leaf samples from 300 plants from all of the Tephrosia accessions were collected from different field sites (Suppl. Table 1) and tested again by dot-blot assay using the same antisera, in three consecutive years. Leaves collected from a maximum of 10 plants 
from one accession were considered as one sample for the primary screening of virus in the dot-blot assay as per the ILRI's standard operating procedures for virus detection.

Out of 20 samples collected from the field during the 2015 planting season (Suppl. Table 1), one sample (T. linearis; Acc. no. 17684) showed weak reactivity with BCMV antisera, one (T. spp.; Acc. no. 12960) with PeMoV and four (T. hookeriana; Acc. no. 23937, T. interrupta; Acc. no. 23943, T. rosea; Acc. no. 24024, T. senna; Acc. no. 24030) with CMV antisera in a dot-blot assay. In the subsequent 2016 and 2017 planting seasons, out of 30 samples collected from the field, only one sample (T. spp.; Acc. no. 820), collected from the Ziway screenhouse showed reactivity with CMV antisera in a dot-blot assay (Suppl. Table 1). Further to this, individual plants of Tephrosia spp. (Acc. no. 820) were tested by dot-blot assay, where $50 \%$ of the plants showed reactivity with CMV antisera. It was also observed that only plants grown at the Ziway site were found to be infected with CMV whereas Tephrosia spp. (Acc. no. 820), which was found to be infected in 2016, was originally planted and tested in 2015 and found to be healthy at that time. Therefore, we conclude that the plants are being infected by CMV at the Ziway site with the isolate present at that location.

The association of CMV with Tephrosia was further confirmed through reverse transcriptase polymerase chain reaction (RT-PCR). Total genomic RNA was extracted from the symptomatic and asymptomatic leaves of Tephrosia spp. that showed weak reactivity with antisera to BCMV, CMV and PeMoV using a Trizol method (Chomczynski and Sacchi 1987). RNA was also extracted from BCMV, CMV and PeMoV infected lyophilized tissue (DSMZ, Germany) for use as positive controls. Briefly, approximately $100 \mathrm{mg}$ of leaf tissue was ground under liquid nitrogen and mixed with $1 \mathrm{ml}$ of Trizol reagent (Thermo Fisher Scientific, USA) followed by separation of phases using chloroform. The RNA present in the aqueous phase was precipitated using isopropyl alcohol, washed in $75 \%$ ethanol and re-dissolved in RNase-free water.

The primers for BCMV (GBV49F; agacacgtggatgttagtcett / GBV50R; actatatgaaattattcagcgacg) and PeMoV (GBV30F; ga a c catgaga atg c c a tggttgg / GBV31 R; gtcgacaccatcaagaccaaatgtcttaat) were designed to the conserved region of the coat protein gene from the available sequences in the NCBI database using the BioEdit sequence alignment editor software (Hall 1999) and validated for RT-PCR using the positive control samples (data not shown). Primers and conditions for the RT-PCR analysis of CMV were as described by Bashir et al. (2006).

The first strand cDNA was synthesized in a $20 \mu \mathrm{l}$ reaction volume containing $4 \mu \mathrm{l}$ of $5 \mathrm{x}$ First-Strand buffer, $1 \mu \mathrm{l}$ of $10 \mathrm{mM}$ dNTP mix, $1 \mu \mathrm{l}$ of $10 \mu \mathrm{M}$ each forward and reverse primer, $1 \mu \mathrm{l}$ of 200 Units/ $\mu$ l RevertAid ${ }^{\mathrm{TM}} \mathrm{M}-\mathrm{MuLV}$ reverse transcriptase (Thermo Fisher Scientific, USA), $10 \mu \mathrm{l}$ of RNA template (400-500 ng), and the final volume was adjusted with nuclease free water. First strand cDNA synthesis was effected by heating the mixture to $42^{\circ} \mathrm{C}$ for $60 \mathrm{~min}$ followed by inactivation at $70{ }^{\circ} \mathrm{C}$ for $15 \mathrm{~min}$ in a thermal cycler (Eppendorf, Germany). PCR analysis was carried out in a $25 \mu \mathrm{l}$ reaction volume containing $1 \mu \mathrm{l}$ of cDNA, 1x PCR buffer, $2 \mathrm{mM}$ dNTPs, $0.5 \mu \mathrm{M}$ of each primer and 0.5 units of Phusion High-Fidelity Taq DNA polymerase (Thermo Fisher Scientific, USA) in a thermal cycler (Eppendorf, Germany). Conditions were an initial denaturation step at $98^{\circ} \mathrm{C}$ for $30 \mathrm{~s}$ followed by 35 cycles of $98^{\circ} \mathrm{C}$ for $10 \mathrm{~s}, 52-$ $55^{\circ} \mathrm{C}$ for $30 \mathrm{~s}$, and $72{ }^{\circ} \mathrm{C}$ for $30 \mathrm{~s}$ and a final extension step at 72 ${ }^{\circ} \mathrm{C}$ for $10 \mathrm{~min}$. The amplified fragments were resolved on a $1.0 \%$ agarose gel by electrophoresis and visualized in a UV gel documentation system (Intas, Germany).

The amplified products were purified using a gel purification kit following the standard instructions (Thermo Fisher Scientific, USA), sequenced using PCR primers of the commercial facilities of Bioneer, Republic of Korea and the sequences were analyzed by Basic Local Alignment Search Tool (BLAST) analysis (http://www.ncbi.nlm.nih.gov/blast). The sequences were assembled and open reading frames predicted using ORF finder (http://www.ncbi.nlm.nih.gov/ gorf/gorf.html). The sequences were compared with the available CMV coat protein (CP) sequences in the NCBI databases using BioEdit (Hall 1999). The phylogenetic analyses were conducted by MEGA6 (Tamura et al. 2013) using the parsimony method with 500 bootstrap values based on the nucleotide sequences of the coat protein gene of CMV isolates reported worldwide with peanut stunt virus (Accession no. JN135292) as an outgroup (Fig. 1).

The RT-PCR performed with BCMV and PeMoV specific primers for serologically positive samples of Tephrosia linearis and Tephrosia spp., respectively did not amplify a product even after repeated attempts, whereas the RT-PCR performed with CMV specific primers for the above mentioned four serologically positive samples collected from Ziway during 2015 planting season, amplified a product of the expected size (867 bp) with the $T$. senna sample only. The reason for not getting amplification in other dot-blot weak positive samples may be because of the absence of virus in the samples, and weak reactivity in the dot-blot might be due to non-specific binding of antibodies with other proteins.

The BLAST analysis of the sequences generated from the PCR products confirmed the presence of CMV in the sampled T. Senna plants showing yellow leaf symptoms. The various isolates/strains of CMV are classified into two subgroups, -I and -II, based on their biological, serological and molecular properties (Palukaitis and Zaitlin 1997). Subgroup-I shares 92-95\% identity but has been further divided into two groups, IA and IB based on the diversity of the CP gene and 5' untranslated region (UTR) nucleotide sequence. Subgroup-I shares approximately $75 \%$ nucleotide sequence identity with the members of subgroup-II (Palukaitis and Zaitlin 1997; Roossinck et al. 1999; Roossinck 2001). 


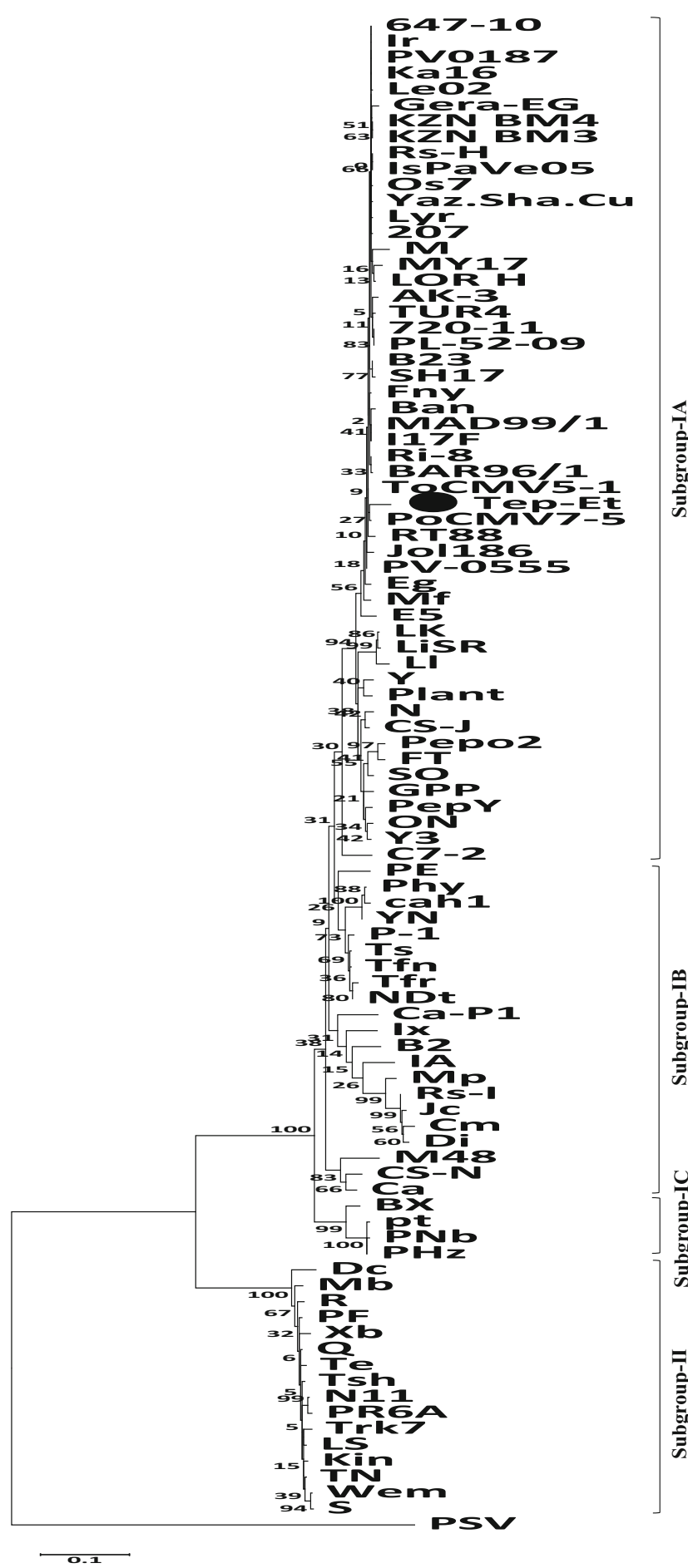

Fig. 1 A parsimony tree constructed by MEGA6 with 500 bootstrap values based on the nucleotide sequences of the coat protein gene of cucumber mosaic virus showing the evolutionary clustering of Tephrosia isolate (Tep-Et) from Ethiopia with 93 isolates reported worldwide. The isolate; Tep-Et clustered in subgroup-IA whereas, the peanut stunt virus is used as an outgroup species for this analysis. Description of CMV isolates is as in Suppl. Table 2

The sequences generated from the PCR products were trimmed from both sides and a cleaned sequence of $657 \mathrm{bp}$, encoding the $\mathrm{CP}$ gene, was extracted and submitted to the
NCBI database under accession on. KY041651. A comparison of the CP gene sequence of the present isolate (Tep-Et) with 93 other CP gene sequences of CMV isolates reported worldwide revealed that the present isolate shared greatest sequence similarity with subgroup-I isolates $(88.8-97.5 \%$ nucleotide (nt) and 89.4-96.3\% amino acid (aa) sequence identity) whereas it shared only $74.5-76.0 \%$ nt and $75.7-79.4 \%$ aa sequence identity with the members of subgroup-II (Suppl. Table 2). This finding is consistent with expectations as Ethiopia comes under the tropical and subtropical region and the CMV subgroup I should predominate in this region of the world (Haase et al. 1989). The sequence identity based on the $\mathrm{CP}$ gene sequences of Tep-Et and other isolates confirmed the identity of Tep-Et as a member of subgroup-I. A phylogenetic analysis based on the nt sequence of the $\mathrm{CP}$ gene of $93 \mathrm{CMV}$ isolates showed four evolutionary subgroupings- IA, IB, IC and II, as reported by Geetanjali et al. (2011). The Tep-Et isolate clustered with subgroup IA and is flanked by two Syrian isolates; ToCMV5-1 and PoCMV7-5 as expected by sequence identity analysis (Fig. 1).

Many researchers have worked on the detection, identification and isolation of CMV from different crops in Ethiopia as it is an important virus in the country, however, limited success has been reported about its control in the country (Abraham and Makkouk 2002). The accurate identification of the virus strain, and their source of infections are important factors in deciding the management practice use to combat the disease. The present study for the first time describes the detection and molecular characterization of CMV causing yellow leaf disease on Tephrosia in Ethiopia and identifies the isolate as a member of subgroup-IA that strengthens previous observations (Haase et al. 1989). However, there is also a need to identify the source of the virus infection to identify a suitable management practice. CMV has a wide host range and infects more than 1,200 plant species but to the best of our knowledge this is the first report of CMV infection in Tephrosia and this finding will help in ensuring a disease free future for Tephrosia seed production in Ethiopia.

Acknowledgements We acknowledge the support of CGIAR Research Program for Managing and Sustaining Crop Collections for their financial support. Also acknowledge International Center for Tropical Agriculture (CIAT), International Institute of Tropical Agriculture (IITA), International Center for Agricultural Research in the Dry Areas (ICARDA) and International Crops Research Institute for the SemiArid Tropics (ICRISAT) for kindly providing the antisera for the detection of AMV, CPMoV, CMV, PsbMV, PeMoV, respectively. ILRI fully supports the publication of open access articles.

Open Access This article is licensed under a Creative Commons Attribution 4.0 International License, which permits use, sharing, adaptation, distribution and reproduction in any medium or format, as long as you give appropriate credit to the original author(s) and the 
source, provide a link to the Creative Commons licence, and indicate if changes were made. The images or other third party material in this article are included in the article's Creative Commons licence, unless indicated otherwise in a credit line to the material. If material is not included in the article's Creative Commons licence and your intended use is not permitted by statutory regulation or exceeds the permitted use, you will need to obtain permission directly from the copyright holder. To view a copy of this licence, visit http://creativecommons.org/licenses/by/4.0/.

\section{References}

Abraham A, Makkouk KM (2002) The incidence and distribution of seed-transmitted viruses in pea and lentil seed lots in Ethiopia. Seed Sci Technol 30:567-574

Akande TO, Adeyeri MK, Longe OG (2008) Nutritional and Economic Value of Leaf Meal (Tephrosia bracteolata) in Diet of Laying Hens. J Anim Vet Adv 7:784-788

Babayemi OJ, Bamikole MA (2006) Effects of Tephrosia candida DC leaf and its mixtures with Guinea grass on in vitro fermentation changes as feed for ruminants in nigeria. Pak J Nut 5:14-18

Bashir NS, Kalhor MR, Zarghani SN (2006) Detection, differentiation and phylogenetic analysis of cucumber mosaic virus isolates from cucurbits in the northwest region of Iran. Virus Genes 32:277-288

Chomczynski P, Sacchi N (1987) Single Step Method of RNA Isolation by Acid Guanidinium Thiocyanate-Phenol-Chloroform Extraction. Anal Biochem 162:156-159

Dzenda T, Ayo JO, Adelaiye AB, Adaudi AO (2007) Ethnomedical and veterinary uses of Tephrosia vogelii Hook F (Fabaceae): a Review. Niger Vet J 28:24-39

Geetanjali AS, Kumar R, Srivastava PS, Mandal B (2011) Biological and Molecular Characterization of two distinct tomato strains of cucumber mosaic virus based on complete RNA-3 genome and subgroup specific diagnosis. Indian J Viorol 22:117

Haase A, Richter J, Rabenstein F (1989) Monoclonal antibodies for detection and serotyping of cucumber mosaic virus. Phytopathology 127:129-136

Hall TA (1999) BioEdit: a user-friendly biological sequence alignment editor and analysis program for Windows 95/98/NT. Nucleic Acids Symp Ser 41:95-98

Mbomi SE, Ogungbesan AM, Babayemi OJ, Nchinda VP (2011) Chemical composition, acceptability of three Tephrosia species and use of Tephrosia purpurea as supplement for grazing animals in the western highlands of Cameroon. J Env Issues Agri Dev Countries 3:132-139

Palukaitis P, Zaitlin M (1997) Replicase-mediated resistance to plant virus disease. Adv Virus Res 48:349-377

Qureshi R, Bhatti GR, Memon RA (2010) Ethnomedicinal uses of herbs from northern part of NARA desert, Pakistan. Pak J Bot 42:839-851

Roossinck MJ (2001) Cucumber mosaic virus, a model for RNA virus evolution. Mol Plant Pathol 2:59-63

Roossinck MJ, Zhang L, Hellwald KH (1999) Rearrangements in the 5' non-translated region and phylogenetic analyses of cucumber mosaic virus RNA 3 indicate radial evolution of three subgroups. J Virol 73:6752-6758

Tamura K, Stecher G, Peterson D, Filipski A, Kumar S (2013) MEGA6: Molecular Evolutionary Genetics Analysis version 6.0. Mol Biol Evol 30:2725-2729

Wang Z, Yu D, Li X, Zeng M, Chen Z, Bi L, Liu J, Jin L, Hu D, Yang S, Song B (2012) The development and application of a Dot-ELISA assay for diagnosis of southern rice black-streaked dwarf disease in the field. Viruses 4(1):167-183 